\title{
Efficacy of epidermal growth factor receptor (EGFR)-tyrosine kinase inhibitors (TKIs) in targeted therapy of lung squamous cell carcinoma patients with EGFR mutation: a pooled analysis
}

\author{
Jingqi Zhuang ${ }^{1}$, Yongfeng Yu${ }^{1}$, Ziming $\mathbf{L i}^{1}$ and Shun Lu ${ }^{1}$ \\ 1 Department of Oncology, Shanghai Chest Hospital, Shanghai JiaoTong University, Shanghai, People's Republic of China \\ Correspondence to: Shun Lu, email: Iushun1964@126.com \\ Keywords: efficacy, lung squamous cell carcinoma, epidermal growth factor receptor mutation, tyrosine kinase inhibitors, pooled \\ analysis \\ Received: January 02, $2017 \quad$ Accepted: February 01, 2017 Published: February 25, 2017 \\ Copyright: Zhuang et al. This is an open-access article distributed under the terms of the Creative Commons Attribution License 3.0 (CC BY \\ 3.0), which permits unrestricted use, distribution, and reproduction in any medium, provided the original author and source are credited.
}

\section{ABSTRACT}

Purpose: This pooled analysis aims to evaluate the efficacy of epidermal growth factor receptor (EGFR)-tyrosine kinase inhibitors (TKIs) in lung squamous cell carcinoma with EGFR mutation.

Methods: Advanced stage (IIIB/IV) lung squamous cell carcinoma patients with EGFR mutations treated with EGFR-TKIs were extracted from the publications searched from the databases of EMBASE, Medline (Ovid SP), Web of Science, Cochrane library, PubMed Publisher, ASCO meeting abstract and Google Scholar before August 2016, or identified from the database of Shanghai Chest Hospital from July 2014 to August 2016. Pooled objective response rate, disease control rate and median progression-free survival were accessed directly or by Kaplan-Meier method and combined in different studies by Comprehensive Meta Analysis software via one-group dichotomous or continuous analysis functions.

Results: The combined objective response rate, disease control rate and median progression-free survival were $31.6 \%$ (95\%CI, $24.1 \%$ 40.2\%), $72.0 \%$ (95\% CI, $63.5 \%$ 79.2\%) and 3.08 months (95\% CI, 2.31-3.84 months) in lung squamous cell carcinoma patients with EGFR mutation.

Conclusion: The EGFR-TKIs had a modest response for EGFR mutated lung squamous cell carcinoma patients and might be a selective option for those patients.

\section{INTRODUCTION}

Squamous cell lung cancer accounts for about $25-30 \%$ of NSCLC.[1] Progress in the management of advanced lung squamous cell carcinoma (LSCC) has been lagged behind.[2] For example, pemetrexed monotherapy and platinum-based doublet chemotherapy was not approved in patients with squamous histology because of inferior efficacy.[3] Nonetheless, bevacizumab, the vascular endothelial growth factor (VEGF) inhibitor, was contraindicated in LSCC due to pulmonary hemorrhage [4-6].

In the last decade, the FDA had approved targeted agents as initial treatment for patients with NSCLC, including gefitinib, erlotinib, and afatinib for the patients with EGFR mutations. Recent series including the Lux-
Lung 8, [7] a meta-analysis [8] and a review [9] had shown that EGFR-TKIs had a modest therapeutic effect in unselected patients with advanced LSCC, strengthening the potential efficacy of EGFR targeted therapy in EGFR mutated LSCC. Even it has been proved that EGFRTKIs had a better response in EGFR mutation selected lung adenocarcinoma, whether the EGFR-mutated LSCC patients can benefit more from the EGFR-TKIs remains unclear. However, former pooled frequency of LSCC patients with EGFR mutations was only about 5\% both in Asian and non-Asian, [10] which made it difficult to undergo a further investigation by big scale randomized clinical trials.

Even though, further clarification of this issue was still necessary and important to find more treatment options for LSCC patients. Preliminarily literature 
Table 1: The grouped data extracted from eight studies in the first-cohort.

\begin{tabular}{|c|c|c|c|c|c|c|c|c|}
\hline Reference & Country & \begin{tabular}{|l|} 
EGFR \\
mutation \\
status \\
\end{tabular} & \begin{tabular}{|l|} 
Gefitinib \\
/Erlotinib \\
/Icotinib
\end{tabular} & Response & ORR & DCR & $\begin{array}{l}\text { median PFS } \\
95 \% \text { CI }\end{array}$ & $P$ value \\
\hline \multirow[t]{2}{*}{ Fang2013 } & China & Yes, $n=15$ & NA & 4PR, 6SD, 5PD & $26.70 \%$ & $66.70 \%$ & $3.9(1.5-6.3)$ & 0.19 \\
\hline & & No, $n=48$ & NA & 1PR, $19 \mathrm{SD}, 28 \mathrm{PD}$ & $2.10 \%$ & $41.70 \%$ & $1.9(0.7-3.2)$ & \\
\hline \multirow[t]{2}{*}{ Fiala2013 } & Czech & Yes, $n=16$ & $11 / 5$ & NA & NA & NA & $2.9\left(2.33-3.47^{*}\right)$ & 0.425 \\
\hline & & No, $n=163$ & $80 / 83$ & NA & NA & NA & $1.9(1.75-2.05 *)$ & \\
\hline \multirow[t]{2}{*}{ Hata2013 } & Japan & Yes, $n=20$ & $18 / 2$ & 1CR, 4PR, 6SD, 7PD,2NA & $25.00 \%$ & $50.00 \%$ & $1.4(0.7-5.8)$ & 0.1734 \\
\hline & & No, $n=33$ & $1 / 32$ & 0CR, 3PR, 11SD, 8PD, 1NA & $9.10 \%$ & $42.40 \%$ & $1.8(1.0-2.4)$ & \\
\hline \multirow[t]{2}{*}{ Park2009 } & Korean & Yes, $n=3$ & $3 / 0$ & $3 \mathrm{OR}$ & $100 \%$ & $100 \%$ & 5.8 & 0.07 \\
\hline & & No, $n=17$ & $17 / 0$ & $1 \mathrm{OR}$ & $6.00 \%$ & $\mathrm{NA}$ & 2.4 & \\
\hline \multirow[t]{2}{*}{ Song2013 } & China & Yes, $n=4$ & NA & $3 \mathrm{OR}$ & $75.00 \%$ & $\mathrm{NA}$ & $7.0(4.88-10.93 *)$ & $<0.001$ \\
\hline & & No, $n=70$ & NA & $4 \mathrm{OR}$ & $5.71 \%$ & NA & 1.93 & \\
\hline \multirow[t]{2}{*}{ Song2015 } & China & Yes, $n=4$ & NA & NA & NA & NA & 8.0(4.44-11.56) & 0.235 \\
\hline & & No, $n=70$ & NA & NA & NA & NA & $1.53(1.20-1.86)$ & \\
\hline \multirow[t]{2}{*}{ Xu2015 } & China & Yes, $n=22$ & $7 / 11 / 4$ & 7PR, 11SD, 4PD & $31.80 \%$ & $81.80 \%$ & $3.94(2.73-5.15)$ & 0.004 \\
\hline & & No, $n=27$ & $8 / 13 / 6$ & 15SD, 12PD & $0 \%$ & $51.60 \%$ & $1.94(0.89-2.99)$ & \\
\hline Xu2016 & China & Yes, $n=26$ & NA & 8PR, 11SD,7PD & $30.77 \%$ & $73.08 \%$ & $3.98(3.32-4.63)$ & NA \\
\hline
\end{tabular}

Abbreviations: ORR, object response rate; DCR, disease control rate; median PFS, median Progression-free survival; 95\% CI, 95\% confidence interval; CR, complete response; PR, partial response; OR, object response (CR or PR); SD, stable disease; $\mathrm{PD}$, progression disease; NA, not savailable;

Note: * The $95 \%$ CIs were calculated by the Kaplan-Meier method via the data got from the survival curves.

search had found several studies published dealing with the treatment of EGFR-TKIs in EGFR mutated LSCC patients. In this study, we performed a pooled analysis to evaluate the efficacy of EGFR-TKIs in LSCC patients with EGFR mutations.

\section{RESULTS}

\section{Literatures search and patient allocation}

A total of 71 potential records remained enrolled for full-text assessment after screened from the manual search. Of these, 32 studies were eligible for subsequent pooled analysis (Figure 1). One hundred and ten EGFR mutated LSCC patients with grouped data in the eight studies were assigned as the first-cohort (Table 1). Another forty-four EGFR mutated LSCC patients in 24 studies with individual data and six patients from the Shanghai Chest Hospital database were allocated as the second-cohort (Supplemental Table 1). The flow diagram of inclusion was showed in the Figure 1.

\section{Characteristics of the EGFR mutated LSCC patients in the first-cohort}

In the first-cohort, data was extracted in eight retrospective studies (Table 1), [11-18] including a total of 110 LSCC patients with EGFR mutation and 428
LSCC patients with EGFR wild type. Seven (87.5\%) of the studies were from East Asia, another one from the Europe. The objective response rate (ORR), disease control rate (DCR), median progression-free survival (PFS) and median overall survival (OS) were available in six, four, eight and five studies. Seven studies contained LSCC patients of the EGFR mutation group and EGFR wild type group.

\section{EGFR mutation status in the first-cohort and the response of EGFR-TKIs}

In the first-cohort, six studies reported the EGFR mutation status in a total of 86 LSCC patients with EGFR mutation. Fifty of them were exon 19 deletion, thirty-four were exon 21 L858R, and two were other types. Patients were treated with erlotinib, gefitinib and icotinib, as recorded in the publications. The response, ORR, DCR, and median PFS and the company 95\% CI were extracted and shown in Table 1.

\section{Characteristics of the EGFR mutated LSCC patients in the second-cohort}

In the second-cohort (Supplemental Table 1), there were fifty LSCC patients harboring EGFR mutations. [19-42] Most of these patients were form East Asia. The median age was 63 years, ranging from 29 to 80 years old. Thirty-four and eleven patients were male and female, 
with the gender of other five patients unknown. The number of smoker and non-smoker were 21 and 22, with 7 unknown. The characteristics were shown in Table 2.

\section{EGFR mutation status and the response of EGFR- TKIs in the second-cohort}

In the second-cohort, EGFR mutation were defined as exon 19 deletion $(n=19)$, exon $21 \mathrm{~L} 858 \mathrm{R}(n=13)$, other mutation type were exon18 G719S, Y727H, L692P, E711K, A702S, G721A, exon 20 A763V, N826S, A859T, Q787Q, V843I, K860E, E709K, co-mutation of exon 18 E709K+ exon $21 \mathrm{~L} 858 \mathrm{R}$, exon $19 \mathrm{del}+$ exon $21 \mathrm{~L} 858 \mathrm{R}$, exon $20 \mathrm{~T} 790 \mathrm{M}+$ exon $21 \mathrm{~L} 858 \mathrm{R}$, exon $21 \mathrm{~L} 838 \mathrm{P}+$ E868G. Patients were treated with gefitinib $(n=32)$, erlotinib $(n=17)$ or icotinib $(n=1)$. The ORR, DCR and median PFS were 34.78\% (16/46), 73.91\%(34/46), 3.0 months (Figure 2, $n=30,95 \% \mathrm{CI}, 2.525-3.425$ months) in LSCC patients with EGFR mutation.

\section{Combined ORR, DCR and PFS of the first-cohort and second-cohort}

Combined ORR, DCR and PFS were calculated (Figure 3) without engaging the data contained less than five patients in any group. The combined ORR was $31.6 \%(n=127,95 \%$ CI, 24.1\% 40.2\%; random-effect, Q statistic $\left.=0.513, \mathrm{I}^{2}<0.001\right)$ in LSCC with EGFR mutation versus $7.5 \%(n=147,95 \% \mathrm{CI}, 4.0 \% \sim 13.7 \%$, randomeffect, Q statistic $\left.=3.533, \mathrm{I}^{2}=0.000\right)$ in LSCC with EGFR wild type. The combined DCR were $72.0 \%(n=127,95 \%$ CI, 63.5\% 79.2\%, random-effect, Q statistic $=2.371, \mathrm{I}^{2}$ $<0.001$ ) in LSCC with EGFR mutation versus $45.8 \%$ ( $n$ $=107,95 \% \mathrm{CI}, 36.6 \% \sim 55.3 \%$, random-effect, Q statistic $\left.=1.406, \mathrm{I}^{2}<0.001\right)$ in LSCC with EGFR wild type. The combined median PFS was 3.08 months $(n=129,95 \%$ CI, 2.31-3.84 months, random-effect, Q statistic $=5.518$, $\left.\mathrm{I}^{2}=9.391\right)$ in LSCC with EGFR mutation versus 1.85 months in wild type $(n=428,95 \%$ CI, $1.72-1.97$ months, fix-effect, Q statistic $\left.=5.393, \mathrm{I}^{2}<0.001\right)$.

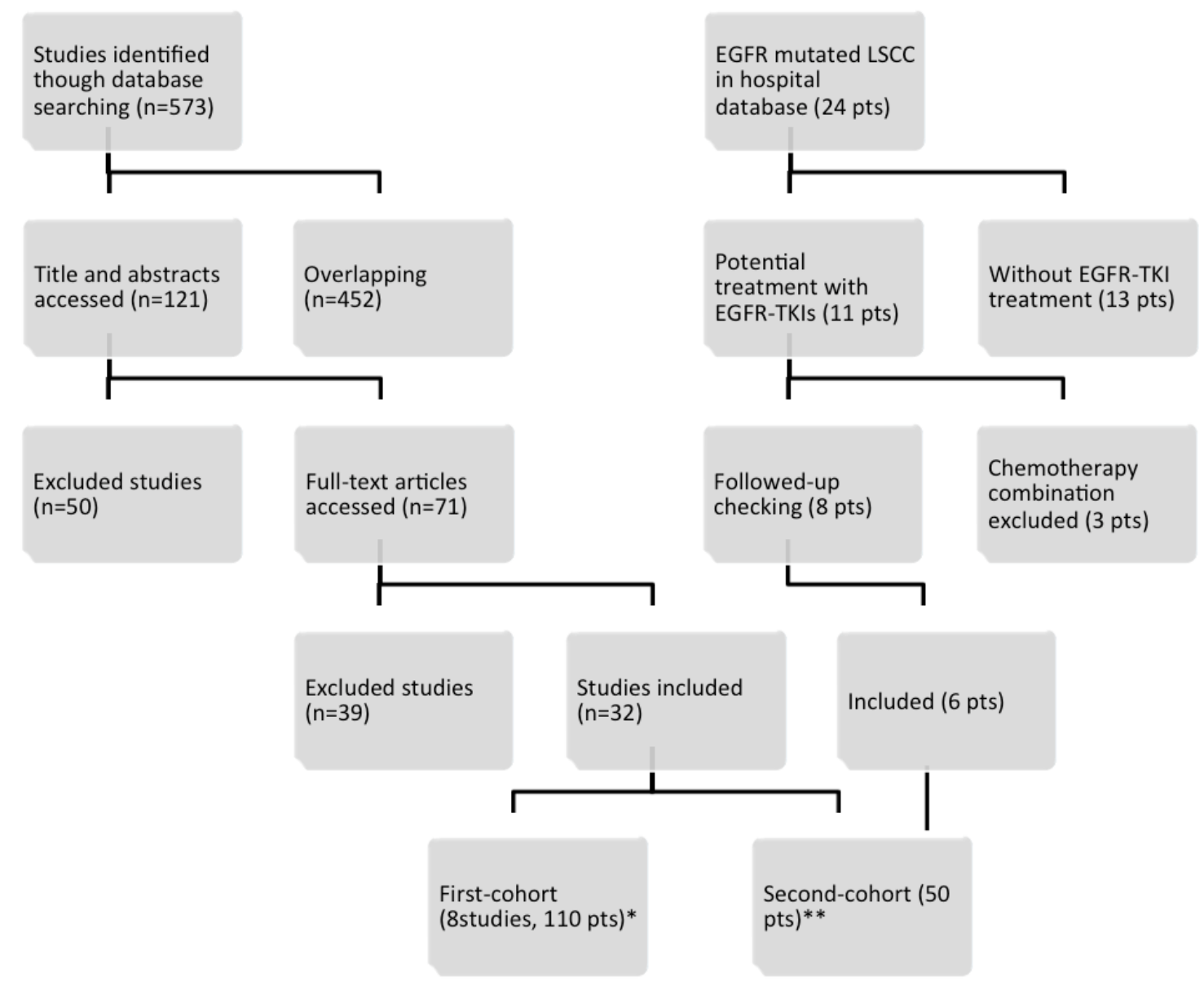

Figure 1: Flow diagram of literature search and eligibility. Note: *EGFR mutated LSCC patients with grouped data were assigned as the first-cohort. ** EGFR mutated LSCC patients with individual data and patients from the Shanghai Chest Hospital database were allocated as the second-cohort. 
Table 2: The characteristics of LSCC with EGFR mutations in the second-cohort.

\begin{tabular}{|c|c|}
\hline Characteristics & LSCC $(n=50)$ \\
\hline \multicolumn{2}{|l|}{ Age } \\
\hline$<65$ & 18 \\
\hline$>65$ & 9 \\
\hline NA & 23 \\
\hline Median & $63(29-80)$ \\
\hline \multicolumn{2}{|l|}{ Sex } \\
\hline Male & 34 \\
\hline Female & 11 \\
\hline NA & 5 \\
\hline \multicolumn{2}{|l|}{ ECOG PS } \\
\hline 0 & 2 \\
\hline 1 & 9 \\
\hline 2 & 0 \\
\hline 3 & 3 \\
\hline 4 & 1 \\
\hline NA & 35 \\
\hline \multicolumn{2}{|l|}{ Smoke } \\
\hline YES & 22 \\
\hline $\mathrm{NO}$ & 21 \\
\hline NA & 7 \\
\hline \multicolumn{2}{|l|}{\begin{tabular}{|l|} 
TKI \\
\end{tabular}} \\
\hline Gefitinib & 32 \\
\hline Erlotinib & 17 \\
\hline Icotinib & 1 \\
\hline \multicolumn{2}{|l|}{ Mutation } \\
\hline Exon $19 \mathrm{del}$ & 19 \\
\hline Exon 21 L858R & 13 \\
\hline 19del+21L858R & 2 \\
\hline G719S & 1 \\
\hline Others & 15 \\
\hline \multicolumn{2}{|l|}{ Treatment sequence } \\
\hline 1 & 8 \\
\hline 2 & 12 \\
\hline$\geq 3$ & 5 \\
\hline NA & 25 \\
\hline \multicolumn{2}{|l|}{ Response } \\
\hline $\mathrm{CR}$ & 1 \\
\hline$\overline{P R}$ & 15 \\
\hline SD & 18 \\
\hline $\mathrm{PD}$ & 12 \\
\hline $\mathrm{NE}$ & 4 \\
\hline
\end{tabular}

Abbreviation: LSCC, lung squamous cell carcinoma; TKI, tyrosine kinase inhibitor; NA, not available; CR, complete response; PR, partial response; $\mathrm{SD}$, stable disease; $\mathrm{PD}$, progression disease; NE, no evaluable.

\section{DISCUSSION}

In 2014, Ameratunga et al had underwent a meta analysis on the efficacy of EGFR-TKIs to LSCC, which reveled that EGFR-TKIs had a modest therapeutic effect compared to placebo in unselected LSCC patients. [8] Then, the phase III trial Lux-Lung 8 had shown hat afatinib versus erlotinib as second-line treatment of patients with EGFR mutation unselected advanced LSCC had significant improvements in PFS.[7] However, these trials did not answer that whether EGFR-TKI had a better efficacy in EGFR mutated LSCC patients compared with EGFR wild LSCC patients.

This pooled analysis is by far the most updated and comprehensive analysis of EGFR-TKIs for EGFR mutated LSCC to answer this question. Takehito et al 2010 had revealed that the EGFR-TKI, gefitinib was less effective in non-adenocarcinoma NSCLC with EGFR mutation than lung adenocarcinoma (LADC) harboring EGFR mutation. [45] Our study found that EGFR mutated LSCC patients had prior response to EGFR-TKIs than EGFR wild type LSCC patients, with higher object response rate $(31.6 \%$ vs. $11.7 \%)$, disease control rate $(72.0 \%$ vs. $42.8 \%)$ and longer progression-free survival (3.08 vs. 1.85 months). This modest priority highlighted that EGFR-TKI might be a better option for EGFR mutated LSCC patients than that with EGFR wild type. However, the median PFS was shorter than that in EGFR mutated LADC.

The mechanism of lower response of EGFR-TKI treatment in LSCC patients with EGFR mutation compared to LADC patients harboring EGFR mutation is under reveling. Lee et al had found that high EGFR gene copy number could be as predictive markers for EGFR-TKI in patients with advanced squamous cell lung carcinoma.[46] Another answer was the genomic variety and complexity of LSCC. The Cancer Genome Atlas Research Network had identified the potential therapeutic gene or pathway alteration of squamous cell lung cancers, revealed that the genomic complexities were more common compared with LADC. [47, 48] Moreover, about half of all patients with LSCC carried multiple gene aberrances and $69 \%$ of the alternation was in the PI3K/ RTK/RAS signaling pathway, which might affect the efficacy of EGFR-TKI.[47] Zhijie Wang et al reported that the resistance of LSCC harboring EGFR mutation to EGFR-TKI was due to the activation of BMP-BMPR-Smad1/5-p70S6K, [49] and the combination of EGFR-TKI with inhibitors of BMP receptors signaling pathway overcame the resistance. Besides, mutationindependent mechanisms likely also contribute to the observed efficacy of EGFR-TKI therapy.[50]

Recently, the immune therapy targeting in PD-1/ PD-L1 pathway had shown its priority than chemotherapy in LADC[51] and LSCC [52, 53]. However, recent pooled analysis found that EGFR mutations and ALK rearrangements were associated with low response rates to PD-1 pathway blockade in NSCLC (mainly in lung adenocarcinoma).[54] This retrospective analysis suggests that the immune therapy of PD-1 pathway blockade may not work so well in EGFR mutated NSCLC patients and EGFR mutation targeted therapy by EGFR TKI in EGFR 


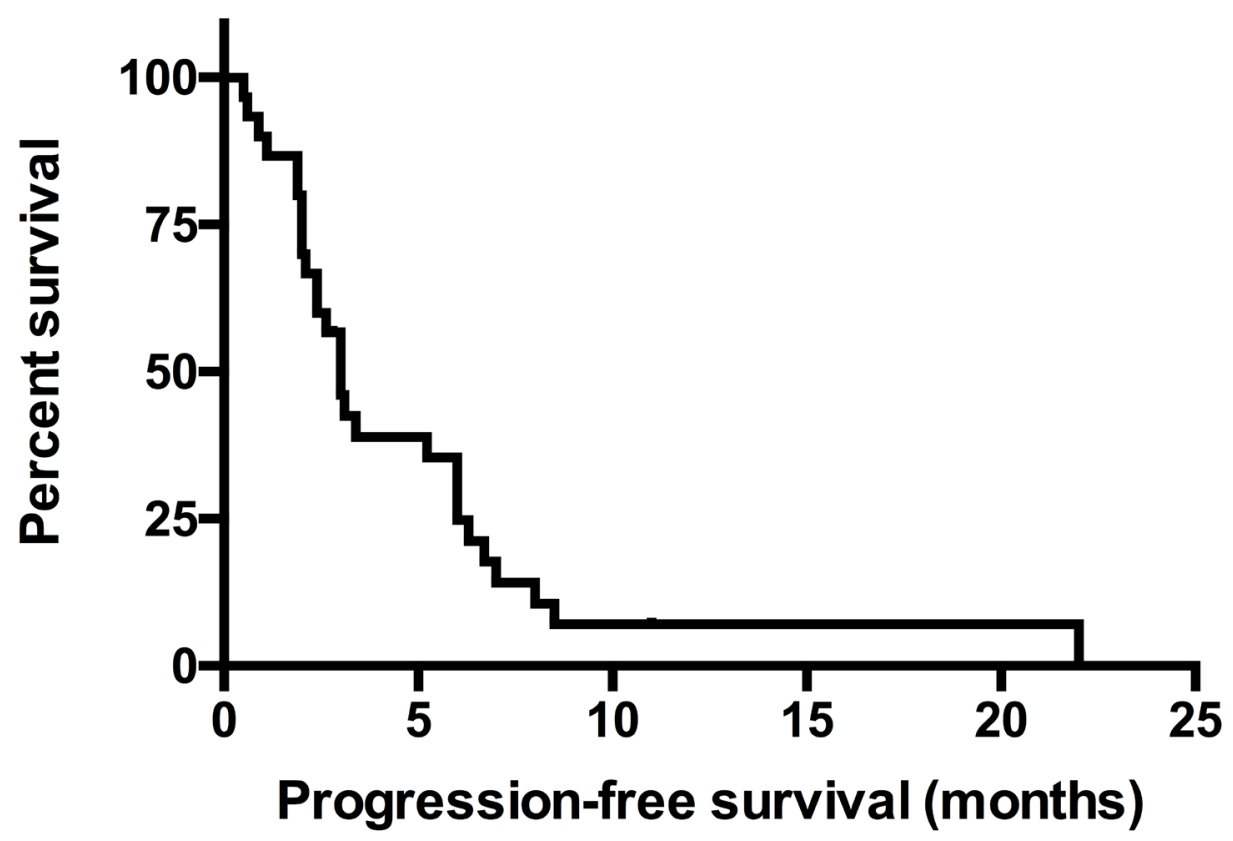

Figure 2: The PFS of EGFR mutated LSCC patients in the second-cohort. The median PFS was 3.0 months $(n=30,95 \%$ CI, 2.525-3.425 months). Abbreviations: LSCC, lung squamous cell carcinoma; PFS, progression-free survival.

A)

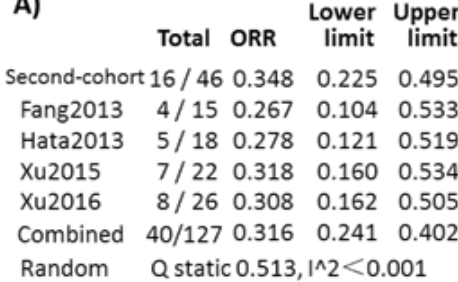

C) Total DCR Lower Upper

Second-cohort 34/46 $0.739 \quad 0.595 \quad 0.845$ $\begin{array}{lllll}\text { Fang2013 } & 10 / 15 & 0.667 & 0.406 & 0.854\end{array}$ $\begin{array}{llllll}\text { Hata2013 } & 11 / 18 & 0.611 & 0.379 & 0.802\end{array}$ $\begin{array}{lllll}\text { Xu2015 } & 18 / 22 & 0.818 & 0.604 & 0.930\end{array}$ $\begin{array}{llllll}\text { Xu2016 } & 19 / 26 & 0.731 & 0.533 & 0.866\end{array}$

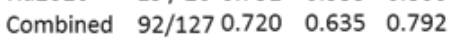
Random Q static $2.371,1 \wedge 2<0.001$

E)
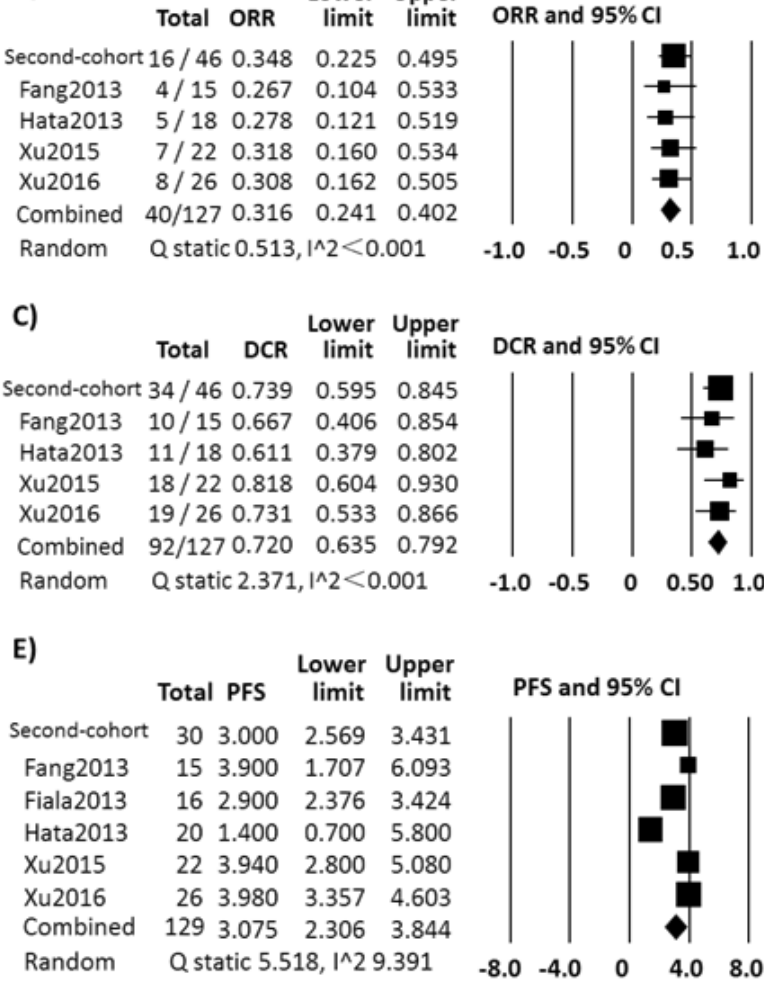

DCR and $95 \% \mathrm{Cl}$

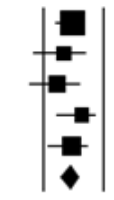

$\begin{array}{lllll}-1.0 & -0.5 & 0 & 0.50 & 1.0\end{array}$
B)

F)

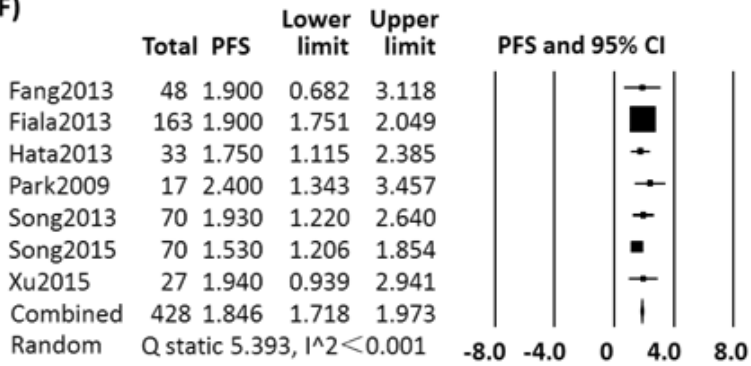

Figure 3: The combined results of first-cohort and second-cohort. ORR in LSCC patients with EGFR mutation A. and with EGFR wild type B. treated with EGFR-TKI; DCR in LSCC patients with EGFR mutation C. and with EGFR wild type D. treated with EGFR-TKI; Median PFS in LSCC patients with EGFR mutation E. and with EGFR wild type F. treated with EGFR-TKI. 
mutated patients might be a very important selection. However, whether it is the same in EGFR mutated LSCC patients remains unknown.

Our studies had limitations. Firstly, this pooled analysis was a retrospective nature. Secondly, the very infrequency of EGFR mutation in LSCC patients had made the discovery so difficult that there were only scattered studies and reports found from the literature search, published in lower impact journals, lacking of crucial clinical information. Even we tried attempting to collect more and better data, the reliability of combining these outcomes was questionable. All of the limitations would affect the likely results. Therefore, further prospective randomized control trials are warranted to make a validation and certification of the results.

In conclusion, our study had reveled that first generation EGFR-TKIs had a modest better efficacy for LSCC patients with EGFR mutation than EGFR wild type LSCC patients, and might be a selective option for those patients with EGFR mutation. Larger prospective randomized control trials are warranted to confirm the efficacy of EGFR-TKIs targeted therapy in EGFR-mutated LSCC patients.

\section{MATERIALS AND METHODS}

\section{Patients}

Advanced stage (IIIB/IV) LSCC patients with EGFR mutations treated with EGFR-TKIs were identified in the database of Shanghai Chest Hospital from July 2014 to August 2016, or extracted from the publications searched from the online medicine databases.

\section{Data sources and search strategy}

First, we systematically searched seven online databases including EMBASE, Medline (Ovid SP), Web of Science, Cochrane library, PubMed, ASCO meeting abstract and Google Scholar before August 2016. The search strategy included keywords and MeSH terms related to therapy using EGFR-TKIs in lung cancer and screened them for eligibility. Second, we identified the patients with EGFR mutated LSCC at the Shanghai Chest Hospital from July 2014 to August 2016 as Supplemental Table 1.

\section{Data extraction}

In the hospital database and searched publications, we extracted the baseline clinical characteristics included age at diagnosis, sex, tumor histology, EGFR mutation status, performance status (PS), smoking history and prior treatment regions. Clinical treatment regimen of EGFRTKI and response outcome was extracted or accessed. Tumor response was assessed by RECIST (version 1.1), WHO criteria and ECOG criteria in the original publications. The same terms from EGFR wild type LSCC patients were also yielded as controls. Data were recorded as individual type and grouped type, which decided the patients into different cohort for analysis.

\section{Statistic methods}

Firstly, in the eight studies with grouped data extracted, which had its outcome of ORR, DCR and median PFS (see Table 1) in each studies, [11-17, 55] were allocated as the first-cohort.

Secondly, the searched patients with the terms extracted individually[19-42] were put as the secondcohort. The ORR and DCR were accounted. The median PFS were generated by the Kaplan-Meier method directly. These statistical analyses were performed using IBM SPSS Statistics version 22.0 for Mac OS.

Thirdly, the ORR, DCR and median PFS of the first-cohort were pooled with those in the secondcohort using Comprehensive Meta Analysis software (Version 3.13) by one-group dichotomous (for ORR and DCR) or continuous analysis functions (for median PFS) (Figure 3) . Homogeneity was tested by the $\mathrm{Q}$ statistic (significance level at $P>0.10$ ) and the $\mathrm{I}^{2}$ statistic (significant heterogeneity, $\mathrm{I}^{2}>50 \%$ ). If there was no significant heterogeneity in the groups, the fixed-effects model (Mantel-Haenszel method) was used. Otherwise, the random-effects model (DerSimonian and Laird method) was used. All tests were two-sided and $\mathrm{P} \geq 0.05$ were considered significant.

\section{Author contributions}

Conception and design: Shun Lu, Jingqi Zhuang

Collection and assembly of data: Jingqi Zhuang, Yongfeng $\mathrm{Yu}$ and Ziming $\mathrm{Li}$

Data analysis and interpretation: all authors

Manuscript writing: all authors

Final approval of manuscript: all authors.

\section{ACKNOWLEDGMENTS}

This work was supported by grants from National Natural Science Foundation of China (81672272), Wu Jie Ping-Roche Medical Special Foundation (320.6750.1388), Shanghai Chest Hospital Science and Technology Development Fund (2014YZDC10600), and Key Project of Shanghai Health and Family Planning Commission (201540365). 


\section{CONFLICTS OF INTEREST}

None of the authors has any personal or financial conflicts of interest.

\section{REFERENCES}

1. Youlden DR, Cramb SM, Baade PD. The International Epidemiology of Lung Cancer: geographical distribution and secular trends. J Thorac Oncol. 2008; 3: 819-31.

2. Langer CJ, Obasaju C, Bunn P, Bonomi P, Gandara D, Hirsch FR, Kim ES, Natale RB, Novello S, Paz-Ares L, Perol M, Reck M, Ramalingam SS, et al. Incremental Innovation and Progress in Advanced Squamous Cell Lung Cancer: Current Status and Future Impact of Treatment. J Thorac Oncol. 2016; 11: 2066-81.

3. Scagliotti G, Brodowicz T, Shepherd FA, Zielinski C, Vansteenkiste J, Manegold C, Simms L, Fossella F, Sugarman K, Belani CP. Treatment-by-histology interaction analyses in three phase III trials show superiority of pemetrexed in nonsquamous non-small cell lung cancer. J Thorac Oncol. 2011; 6: 64-70.

4. Johnson DH, Fehrenbacher L, Novotny WF, Herbst RS, Nemunaitis JJ, Jablons DM, Langer CJ, DeVore RF 3rd, Gaudreault J, Damico LA, Holmgren E, Kabbinavar F. Randomized phase II trial comparing bevacizumab plus carboplatin and paclitaxel with carboplatin and paclitaxel alone in previously untreated locally advanced or metastatic non-small-cell lung cancer. J Clin Oncol. 2004; 22: 218491.

5. Sandler A, Gray R, Perry MC, Brahmer J, Schiller JH, Dowlati A, Lilenbaum R, Johnson DH. Paclitaxelcarboplatin alone or with bevacizumab for non-small-cell lung cancer. N Engl J Med. 2006; 355: 2542-50.

6. Reck M, von Pawel J, Zatloukal P, Ramlau R, Gorbounova V, Hirsh V, Leighl N, Mezger J, Archer V, Moore N, Manegold C. Phase III trial of cisplatin plus gemcitabine with either placebo or bevacizumab as first-line therapy for nonsquamous non-small-cell lung cancer: AVAil. J Clin Oncol. 2009; 27: 1227-34.

7. Soria JC, Felip E, Cobo M, Lu S, Syrigos K, Lee KH, Goker E, Georgoulias V, Li W, Isla D, Guclu SZ, Morabito A, Min YJ, et al. Afatinib versus erlotinib as second-line treatment of patients with advanced squamous cell carcinoma of the lung (LUX-Lung 8): an open-label randomised controlled phase 3 trial. Lancet Oncol. 2015; 16: 897-907.

8. Ameratunga M, Pavlakis N, Gebski V, Broad A, Khasraw M. Epidermal growth factor receptor-tyrosine kinase inhibitors in advanced squamous cell carcinoma of the lung: a meta-analysis. Asia Pac J Clin Oncol. 2014; 10: 273-8.

9. Goss GD, Spaans JN. Epidermal growth factor receptor inhibition in the management of Squamous cell carcinoma of the Lung. Oncologist. 2016; 21: 205-13.

10. Lindeman NI, Cagle PT, Beasley MB, Chitale DA, Dacic
S, Giaccone G, Jenkins RB, Kwiatkowski DJ, Saldivar JS, Squire J, Thunnissen E, Ladanyi M. Molecular testing guideline for selection of lung cancer patients for EGFR and ALK tyrosine kinase inhibitors: guideline from the College of American Pathologists, International Association for the Study of Lung Cancer, and Association for Molecular Pathology. Arch Pathol Lab Med. 2013; 137: 828-60.

11. Fang $W$, Zhang J, Liang W, Huang Y, Yan Y, Wu X, Hu Z, Ma Y, Zhao H, Zhao Y, Yang Y, Xue C, Zhang J, et al. Efficacy of epidermal growth factor receptor-tyrosine kinase inhibitors for Chinese patients with squamous cell carcinoma of lung harboring EGFR mutation. J Thorac Dis. 2013; 5: 585-92.

12. Fiala O, Pesek M, Finek J, Benesova L, Bortlicek Z, Minarik M. Gene mutations in squamous cell NSCLC: insignificance of EGFR, KRAS and PIK3CA mutations in prediction of EGFR-TKI treatment efficacy. Anticancer Res. 2013; 33: 1705-11.

13. Hata A, Katakami N, Yoshioka H, Kunimasa K, Fujita S, Kaji R, Notohara K, Imai Y, Tachikawa R, Tomii K, Korogi Y, Iwasaku M, Nishiyama A, et al. How sensitive are epidermal growth factor receptor-tyrosine kinase inhibitors for squamous cell carcinoma of the lung harboring EGFR gene-sensitive mutations? J Thorac Oncol. 2013; 8: 89-95.

14. Park SH, Ha SY, Lee JI, Lee H, Sim H, Kim YS, Hong J, Park J, Cho EK, Shin DB, Lee JH. Epidermal growth factor receptor mutations and the clinical outcome in male smokers with squamous cell carcinoma of lung. J Korean Med Sci. 2009; 24: 448-52.

15. Song Z, Lin B, Shao L, Zhang Y. Therapeutic efficacy of gefitinib and erlotinib in patients with advanced lung adenosquamous carcinoma. Journal of the Chinese Medical Association. 2013; 76: 481-5.

16. Song Z, Zhang Y. Efficacy of gefitinib or erlotinib in patients with squamous cell lung cancer. Arch Med Sci. 2015; 11: 164-8.

17. Xu J, Chu T, Jin B, Dong X, Lou Y, Zhang X, Wang H, Zhong H, Shi C, Gu A, Xiong L, Zhao Y, Jiang L, et al. Epidermal Growth Factor Receptor Tyrosine Kinase Inhibitors in Advanced Squamous Cell Lung Cancer. Clin Lung Cancer. 2016; 17:309-14.

18. Xu J, Jin B, Chu T, Dong X, Yang H, Zhang Y, Wu D, Lou Y, Zhang X, Wang H, Han B. EGFR tyrosine kinase inhibitor (TKI) in patients with advanced non-small cell lung cancer (NSCLC) harboring uncommon EGFR mutations: A real-world study in China. Lung Cancer. 2016; 96: 87-92.

19. Asahina H, Yamazaki K, Kinoshita I, Sukoh N, Harada M, Yokouchi H, Ishida T, Ogura S, Kojima T, Okamoto Y, Fujita Y, Dosaka-Akita H, Isobe H, et al. A phase II trial of gefitinib as first-line therapy for advanced non-small cell lung cancer with epidermal growth factor receptor mutations. Br J Cancer. 2006; 95: 998-1004.

20. Chou TY, Chiu CH, Li LH, Hsiao CY, Tzen CY, Chang KT, Chen YM, Perng RP, Tsai SF, Tsai CM. Mutation 
in the tyrosine kinase domain of epidermal growth factor receptor is a predictive and prognostic factor for gefitinib treatment in patients with non-small cell lung cancer. Clin Cancer Res. 2005; 11: 3750-7.

21. D'Addario G, Rauch D, Stupp R, Pless M, Stahel R, Mach N, Jost L, Widmer L, Tapia C, Bihl M, Mayer M, Ribi K, Lerch S, et al. Multicenter phase II trial of gefitinib first-line therapy followed by chemotherapy in advanced non-smallcell lung cancer (NSCLC): SAKK protocol 19/03. Ann Oncol. 2008; 19: 739-45.

22. Fidler MJ, Argiris A, Patel JD, Johnson DH, Sandler A, Villaflor VM, Coon Jt, Buckingham L, Kaiser K, Basu S, Bonomi P. The potential predictive value of cyclooxygenase-2 expression and increased risk of gastrointestinal hemorrhage in advanced non-small cell lung cancer patients treated with erlotinib and celecoxib. Clin Cancer Res. 2008; 14: 2088-94.

23. Fukihara J, Watanabe N, Taniguchi H, Kondoh Y, Kimura T, Kataoka K, Matsuda T, Yokoyama T, Hasegawa Y. Clinical predictors of response to EGFR tyrosine kinase inhibitors in patients with EGFR-mutant non-small cell lung cancer. Oncology. 2014; 86: 86-93.

24. Han SW, Kim TY, Hwang PG, Jeong S, Kim J, Choi IS, Oh DY, Kim JH, Kim DW, Chung DH, Im SA, Kim YT, Lee JS, et al. Predictive and prognostic impact of epidermal growth factor receptor mutation in non-small-cell lung cancer patients treated with gefitinib. J Clin Oncol. 2005; 23: 2493-501.

25. Hata A, Katakami N, Kunimasa K, Yoshioka H, Fujita S, Kaji R, Tachikawa R, Tomii K, Imai Y, Iwasaku M, Ishida T. Erlotinib for pretreated squamous cell carcinoma of the lung in Japanese patients. Jpn J Clin Oncol. 2011; 41: 136672.

26. Hsieh MH, Fang YF, Chang WC, Kuo HP, Lin SY, Liu HP, Liu CL, Chen HC, Ku YC, Chen YT, Chang YH, Chen YT, Hsi BL, et al. Complex mutation patterns of epidermal growth factor receptor gene associated with variable responses to gefitinib treatment in patients with non-small cell lung cancer. Lung Cancer. 2006; 53: 311-22.

27. Ichihara S, Toyooka S, Fujiwara Y, Hotta K, Shigematsu H, Tokumo M, Soh J, Asano H, Ichimura K, Aoe K, Aoe M, Kiura K, Shimizu K, et al. The impact of epidermal growth factor receptor gene status on gefitinib-treated Japanese patients with non-small-cell lung cancer. Int J Cancer. 2007; 120: $1239-47$.

28. Jackman DM, Yeap BY, Lindeman NI, Fidias P, Rabin MS, Temel J, Skarin AT, Meyerson M, Holmes AJ, Borras AM, Freidlin B, Ostler PA, Lucca J, et al. Phase II clinical trial of chemotherapy-naive patients $>$ or $=70$ years of age treated with erlotinib for advanced non-small-cell lung cancer. J Clin Oncol. 2007; 25: 760-6.

29. Kim KS, Jeong JY, Kim YC, Na KJ, Kim YH, Ahn SJ, Baek SM, Park CS, Park CM, Kim YI, Lim SC, Park KO. Predictors of the response to gefitinib in refractory nonsmall cell lung cancer. Clin Cancer Res. 2005; 11: 2244-51.
30. Mu XL, Li LY, Zhang XT, Wang MZ, Feng RE, Cui QC, Zhou HS, Guo BQ. Gefitinib-sensitive mutations of the epidermal growth factor receptor tyrosine kinase domain in chinese patients with non-small cell lung cancer. Clin Cancer Res. 2005; 11: 4289-94.

31. Oh IJ, Ban HJ, Kim KS, Kim YC. Retreatment of gefitinib in patients with non-small-cell lung cancer who previously controlled to gefitinib: a single-arm, open-label, phase II study. Lung Cancer. 2012; 77: 121-7.

32. Paik PK, Rekhtman N, Riely GJ, Miller VA, Ladanyi M, Kris MG. Response to EGFR TKIs in never smokers with stage IV EGFR mutant squamous cell carcinoma of the lung (SQCC). Journal of Clinical Oncology. 2011; 29:e18020.

33. Pallis AG, Voutsina A, Kalikaki A, Souglakos J, Briasoulis E, Murray S, Koutsopoulos A, Tripaki M, Stathopoulos E, Mavroudis D, Georgoulias V. 'Classical' but not 'other' mutations of EGFR kinase domain are associated with clinical outcome in gefitinib-treated patients with non-small cell lung cancer. British Journal of Cancer. 2007; 97: 15606.

34. Schwitter M, Rodriguez R, Schneider T, Kluckert T, Brutsche M, Fruh M. Epidermal growth factor receptor mutation in a patient with squamous cell carcinoma of the lung: who should be tested? Case Rep Oncol. 2013; 6: 2638.

35. Sone T, Kasahara K, Kimura H, Nishio K, Mizuguchi M, Nakatsumi Y, Shibata K, Waseda Y, Fujimura M, Nakao S. Comparative analysis of epidermal growth factor receptor mutations and gene amplification as predictors of gefitinib efficacy in Japanese patients with nonsmall cell lung cancer. Cancer. 2007; 109: 1836-44.

36. Tamura K, Okamoto I, Kashii T, Negoro S, Hirashima T, Kudoh S, Ichinose Y, Ebi N, Shibata K, Nishimura T, Katakami N, Sawa T, Shimizu E, et al. Multicentre prospective phase II trial of gefitinib for advanced nonsmall cell lung cancer with epidermal growth factor receptor mutations: results of the West Japan Thoracic Oncology Group trial (WJTOG0403). Br J Cancer. 2008; 98: 907-14.

37. Tanaka K, Hata A, Kida Y, Kaji R, Fujita S, Katakami $\mathrm{N}$, Imai Y. Gefitinib for a poor performance status patient with squamous cell carcinoma of the lung harboring EGFR mutation. Intern Med. 2012; 51: 659-61.

38. Tseng JS, Yang TY, Chen KC, Hsu KH, Chen HY, Chang GC. Retrospective study of erlotinib in patients with advanced squamous lung cancer. Lung Cancer. 2012; 77: 128-33.

39. Weiss GJ, Liman AK, Allen J, Cheung PY, Kukunoor RN. Squamous Cell Carcinoma of the Lung with Metastasis to the GI Tract Associated with EGFR Exon 19 Deletion. Case Rep Med. 2013; 2013: 874836.

40. Xu JM, Han Y, Duan HQ, Gao EM, Zhang Y, Liu XQ, Zhang JS, Toschi L, Galetta D, Azzariti A, Paradiso A. EGFR mutations and HER2/3 protein expression and clinical outcome in Chinese advanced non-small cell lung cancer patients treated with gefitinib. J Cancer Res Clin 
Oncol. 2009; 135: 771-82.

41. Zhang D, Takigawa N, Ochi N, Tanimoto Y, Noujima D, Chen YY, Tanimoto M, Kiura K. Detection of the EGFR mutation in exhaled breath condensate from a heavy smoker with squamous cell carcinoma of the lung. Lung Cancer. 2011; 73: 379-80.

42. Zhang XT, Li LY, Mu XL, Cui QC, Chang XY, Song W, Wang SL, Wang MZ, Zhong W, Zhang L. The EGFR mutation and its correlation with response of gefitinib in previously treated Chinese patients with advanced nonsmall-cell lung cancer. Annals of Oncology. 2005; 16: 1334.

43. Lee $\mathrm{CK}, \mathrm{Wu} \mathrm{YL}$, Ding PN, Lord SJ, Inoue A, Zhou C, Mitsudomi T, Rosell R, Pavlakis N, Links M, Gebski V, Gralla RJ, Yang JC. Impact of Specific Epidermal Growth Factor Receptor (EGFR) Mutations and Clinical Characteristics on Outcomes After Treatment With EGFR Tyrosine Kinase Inhibitors Versus Chemotherapy in EGFRMutant Lung Cancer: A Meta-Analysis. J Clin Oncol. 2015; 33:1958-1965.

44. Fukuoka M, Wu Y, Thongprasert S, Yang C, Chu D, Saijo N, Watkins C, Duffield E, Armour A, Mok T. Biomarker analyses from a phase III, randomized, open-label, first-line study of gefitinib $(\mathrm{G})$ versus carboplatin/paclitaxel $(\mathrm{C} / \mathrm{P})$ in clinically selected patients (pts) with advanced non-small cell lung cancer (NSCLC) in Asia (IPASS). J Clin Oncol. 2009; 27:8006.

45. Shukuya T, Takahashi T, Kaira R, Ono A, Nakamura Y, Tsuya A, Kenmotsu H, Naito T, Kaira K, Murakami H, Endo M, Takahashi K, Yamamoto N. Efficacy of gefitinib for non-adenocarcinoma non-small-cell lung cancer patients harboring epidermal growth factor receptor mutations: a pooled analysis of published reports. Cancer Sci. 2011; 102: 1032-7.

46. Lee Y, Shim HS, Park MS, Kim JH, Ha SJ, Kim SH, Cho BC. High EGFR gene copy number and skin rash as predictive markers for EGFR tyrosine kinase inhibitors in patients with advanced squamous cell lung carcinoma. Clin Cancer Res. 2012; 18: 1760-8.

47. Cancer Genome Atlas Research N. Comprehensive genomic characterization of squamous cell lung cancers. Nature. 2012; 489: 519-25.
48. Cancer Genome Atlas Research N. Comprehensive molecular profiling of lung adenocarcinoma. Nature. 2014; 511: 543-50.

49. Wang Z, Shen Z, Li Z, Duan J, Fu S, Liu Z, Bai H, Zhang Z, Zhao J, Wang X, Wang J. Activation of the BMP-BMPR pathway conferred resistance to EGFR-TKIs in lung squamous cell carcinoma patients with EGFR mutations. Proceedings of the National Academy of Sciences of the United States of America. 2015; 112: 9990-5.

50. Laurie SA, Goss GD. Role of epidermal growth factor receptor inhibitors in epidermal growth factor receptor wild-type non-small-cell lung cancer. Journal of Clinical Oncology. 2013; 31: 1061-9.

51. Borghaei H, Paz-Ares L, Horn L, Spigel DR, Steins M, Ready NE, Chow LQ, Vokes EE, Felip E, Holgado E, Barlesi F, Kohlhaufl M, Arrieta O, et al. Nivolumab versus Docetaxel in Advanced Nonsquamous Non-Small-Cell Lung Cancer. N Engl J Med. 2015; 373: 1627-39.

52. Brahmer J, Reckamp KL, Baas P, Crino L, Eberhardt WE, Poddubskaya E, Antonia S, Pluzanski A, Vokes EE, Holgado E, Waterhouse D, Ready N, Gainor J, et al. Nivolumab versus Docetaxel in Advanced Squamous-Cell Non-Small-Cell Lung Cancer. N Engl J Med. 2015; 373: 123-35.

53. Reck M, Rodriguez-Abreu D, Robinson AG, Hui R, Csoszi T, Fulop A, Gottfried M, Peled N, Tafreshi A, Cuffe S, O'Brien M, Rao S, Hotta K, et al. Pembrolizumab versus Chemotherapy for PD-L1-Positive Non-Small-Cell Lung Cancer. N Engl J Med. 2016; 375: 1823-33.

54. Gainor JF, Shaw AT, Sequist LV, Fu X, Azzoli CG, Piotrowska Z, Huynh TG, Zhao L, Fulton L, Schultz KR, Howe E, Farago AF, Sullivan RJ, et al. EGFR Mutations and ALK Rearrangements Are Associated with Low Response Rates to PD-1 Pathway Blockade in Non-Small Cell Lung Cancer: A Retrospective Analysis. Clin Cancer Res. 2016; 22: 4585-93.

55. Xu J, Zhang Y, Jin B, Chu T, Dong X, Yang H, Wu D, Lou Y, Zhang X, Wang H, Han B. Efficacy of EGFR tyrosine kinase inhibitors for non-adenocarcinoma lung cancer patients harboring EGFR-sensitizing mutations in China. J Cancer Res Clin Oncol. 2016; 142: 1325-30. 